\title{
Dietary inulin intake and age can significantly affect absorption of the faecal marker dysprosium in rats
}

\author{
Charles Coudray*, Christine Feillet-Coudray and Yves Rayssiguier \\ Centre de Recherche en Nutrition Humaine d'Auvergne, Unité Maladies Métaboliques et Micro-nutriments, INRA, Theix, 63122 St \\ Genès Champanelle, France
}

(Received 20 June 2005 - Revised 2 September 2005 - Accepted 19 September 2005)

\begin{abstract}
It is believed that rare earth elements are not absorbed, and thus they are generally used in some mineral absorption studies as a faecal marker. The aim of the present study was to determine the effect of inulin intake and age on dysprosium (Dy) absorption in rats. Eighty male Wistar rats of four different ages $(2,5,10$ and 20 months) were randomised into either a control group or a group receiving $3.75 \%$ inulin in their diet for $4 \mathrm{~d}$ and then $7.5 \%$ inulin until the end of the study. The animals were fed fresh food and water ad libitum for $30 \mathrm{~d}$. The intestinal absorption of Dy was determined from a $4 \mathrm{~d}$ (day 21 to day 25) balance study. Mean faecal Dy recovery (\%) in the eight groups (3 months control, 3 months inulin, 6 months control, 6 months inulin, 11 months control, 11 months inulin, 21 months control, 21 months inulin) was 94.0 (SD 8.6), 64.8 (SD 10.1), 95.8 (SD 9.4), 81.5 (SD 12.1), 98.4 (SD 9.8), 87.8 (SD 9.5), 97.8 (SD 6.2) and 84.9 (SD 10.9), respectively. Our results showed clearly that dietary inulin intake decreased faecal Dy recovery in all four rat groups, and faecal Dy recovery was significantly higher in the old rats (10 and 20 months) than in the young and adult rats. These results show that the faecal recovery (or intestinal absorption) of Dy may vary greatly with nutritional or physiological states such as inulin intake or age. The use of rare earth elements as a faecal marker should be thus validated under each nutritional or physiological state before being employed in mineral absorption studies.
\end{abstract}

Intestinal absorption: Faecal marker: Dysprosium: Inulin: Fermentation: Age: Rat

The technique of faecal isotope balance or faecal isotopic monitoring employing the stable isotope approach is an important experimental tool for investigating the gastrointestinal absorption of minerals and trace elements (Mellon \& Fairweather-Tait, 1997; Patterson \& Veillon, 2001; Fairweather-Tait \& Dainty, 2002). This requires a complete collection of stools for $3-4 \mathrm{~d}$ in rats and $5-10 \mathrm{~d}$ in adult man. In mineral absorption studies based on stable isotope approaches, the use of faecal markers allows researchers to control the faecal collection period or to reduce this period and determine mineral absorption in a small number of stools (Fairweather-Tait et al. 1997; Ulusoy \& Whitley, 2000). This in turn avoids the need to carry out prolonged faecal collections and reduces the amount of stable isotope administered in these studies, which prevents the perturbation of mineral metabolism and reduces the cost of such studies.

In general, the faecal marker should not be absorbable, and its behaviour in the digestive tract should be identical to that of the mineral to be studied. Previous work has shown that the rare earth elements (REE) belonging to the lanthanide group are absorbed in negligible amounts in the mammalian gut (Durbin et al. 1956). They are therefore generally used in some macronutrient and micronutrient absorption studies as a faecal marker in animals (Coudray et al. 1998; Zhao et al. 2003; Jandacek et al. 2004) and man (Hutcheson et al. 1979; Schuette et al. 1993, 2003; Fairweather-Tait et al. 1997; Harvey et al. 2002), and the use of many of REE has been validated by various investigators in normal conditions. The reliability of their use under particular nutritional conditions and physiological states, however, has not been validated.

There is now a growing interest in non-digestible inulintype fructans in nutrition and health (Van Loo et al. 1999; Kaur \& Gupta, 2002); these are fermented by the local microflora, stimulating the growth of bifidobacteria and lactobacilli, and it has been demonstrated that they increase the absorption of minerals, in particular Mg (Ohta et al. 1995; Coudray et al. 2003). Moreover, studies have shown that the ageing gastrointestinal tract becomes less efficient at absorbing some micronutrients, for example $\mathrm{Ca}, \mathrm{Zn}$ and vitamins $\mathrm{D}$ and $\mathrm{B}_{12}$ (Saltzman \& Russell, 1998). As the majority of investigators using REE as a faecal marker have employed dysprosium (Dy) in their studies, the present work was carried out to examine the validity of Dy as a faecal marker in these particular nutritional conditions and physiological states. With that aim, we determined the effect of dietary inulin intake and age on Dy recovery and absorption in rats aged 2-20 months. The work reported in this paper formed part of a larger study examining the effect of dietary inulin intake and ageing on the absorption of nutritional minerals $(\mathrm{Ca}, \mathrm{Mg}, \mathrm{Zn}, \mathrm{Cu})$ in rats (Coudray et al. 2005a,b). 


\section{Materials and methods}

\section{Materials and reagents}

$\mathrm{HNO}_{3}$ (ultrapure), Dy and indium standard solutions (1 g/l) were obtained from Merck (Darmstadt, Germany). All other chemicals were of the highest quality available. Distilled water was used throughout. A Perkin-Elmer 6100DRC system (Perkin-Elmer Instruments, Courteboeuf, France) equipped with a Meinhard nebuliser (Perkin-Elmer) was used for Dy measurement.

\section{Animals and diets}

Eighty male Wistar rats aged 2, 5, 10 or 20 months were purchased from Janvier (Le Genest Saint Ile, France). Two groups were formed from each age bracket to receive either a control diet or a semi-purified diet containing inulin. The composition of these two diets is given in Table 1. Tested inulin (Raftaline) was purchased from Orafti (Tienen, Belgium). Powder diet $(100 \mathrm{~g})$ was made up with $100 \mathrm{ml}$ distilled water to form a kind of semi-liquid food prepared on site each day. Dietary inulin level was maintained at $37.5 \mathrm{~g} / \mathrm{kg}$ during the first $4 \mathrm{~d}$ and then at $75 \mathrm{~g} / \mathrm{kg}$ from day 5 until the end of the experiment. The total duration of the experiment was $30 \mathrm{~d}$. Food and water were given ad libitum. Food consumption and body weight were recorded weekly. Throughout the experiment, the rats were housed two per plastic cage (wire-bottomed to limit coprophagy) until the balance study and were then separated to one per metabolic cage from day 21 to day 30 in a temperature-controlled room $\left(22^{\circ} \mathrm{C}\right)$ with a dark period from 20.00 hours to 08.00 hours. All procedures complied with the Institute's ethical guidelines on the care and use of laboratory animals.

\section{Preparation of dysprosium solution and sample collection}

$\mathrm{DyCl}_{3} 250 \mathrm{mg}$ was dissolved in $20 \mathrm{ml}$ distilled water. The resulting solution was then topped up to $150 \mathrm{ml}$ with distilled water and maintained for several days at $+4^{\circ} \mathrm{C}$ until utilisation. The Dy content was checked before use. The rats

Table 1. Dietary composition $(\mathrm{g} / \mathrm{kg})$ during the experiment

\begin{tabular}{|c|c|c|c|}
\hline & \multirow[b]{2}{*}{ Control } & \multicolumn{2}{|c|}{ Inulin } \\
\hline & & $37.5 \mathrm{~g} / \mathrm{kg}$ & $75 \mathrm{~g} / \mathrm{kg}$ \\
\hline Wheat starch & 650 & $612 \cdot 5$ & 575 \\
\hline Casein & 200 & 200 & 200 \\
\hline Maize oil & 50 & 50 & 50 \\
\hline Cellulose & 50 & 50 & 50 \\
\hline Mineral mix (AIN 1993)* & 35 & 35 & 35 \\
\hline Vitamin mix (AIN 1993)† & 10 & 10 & 10 \\
\hline DL-Methionine & 3 & 3 & 3 \\
\hline Choline bi-tartrate & 2 & 2 & 2 \\
\hline Inulin & 0 & 37.5 & 75 \\
\hline \multicolumn{4}{|c|}{$\begin{array}{l}\text { Titamin mix AIN } 1993 \text { ensures the following vitamin levels in the diet: } \\
\text { thiamin, } 6 \mathrm{mg} / \mathrm{kg} \text {; riboflavin, } 6 \mathrm{mg} / \mathrm{kg} ; \text { pyridoxine, } 7 \mathrm{mg} / \mathrm{kg} \text {; nicotinic } \\
\text { acid, } 30 \mathrm{mg} / \mathrm{kg} \text {; calcium pantothenate, } 16 \mathrm{mg} / \mathrm{kg} \text {; folic acid, } 2 \mathrm{mg} / \mathrm{kg} \text {; } \\
\text { D-biotin, } 0.2 \mathrm{mg} / \mathrm{kg} \text {; cyanocobalamin, } 10 \mu \mathrm{gg} / \mathrm{kg} \text {; vitamin } \mathrm{K}, 50 \mu \mathrm{g} / \mathrm{kg} \text {; } \\
\text { vitamin A, } 4000 \mathrm{IU} / \mathrm{kg} \text {; vitamin E, } 50 \mathrm{lU} / \mathrm{kg} \text {; vitamin D, } 1000 \mathrm{lU} / \mathrm{kg} \text {. }\end{array}$} \\
\hline
\end{tabular}

were transferred to metabolic cages and housed individually $3 \mathrm{~d}$ before the beginning of the balance study to allow them to adapt to their new environment. Animals received approximately $1.7 \mathrm{ml}$ Dy solution by gavage. The faeces of each rat were collected and quantified for four consecutive days (days 21-25), and excreted Dy in this medium and in the gavage solution was quantified by inductively coupled plasma/MS, as described later. The percentage faecal Dy recovery was calculated from $100 \times$ (Dy excreted in the faeces/Administered Dy), and the percentage intestinal Dy absorption was calculated as follows: $100 \times(($ Administered Dy - Dy excreted in the faeces)/Administered Dy).

\section{Analytical procedures}

Faecal materials were dry-ashed $\left(10 \mathrm{~h}\right.$ at $\left.500^{\circ} \mathrm{C}\right)$ and dissolved with concentrated $\mathrm{HNO}_{3}$ and $\mathrm{H}_{2} \mathrm{O}_{2}$ on a heating plate until complete decoloration. The resulting solution was topped up to $10 \mathrm{ml}$ with water and adequately diluted in $1 \% \mathrm{HNO}$, and Dy concentration was determined by inductively coupled plasma/MS (6100DRC; Perkin-Elmer) using Dy as the external standard and indium as the internal standard. The instrument operating conditions were set as follows after optimisation with a solution of indium $1 \mu \mathrm{g} / \mathrm{l}$ : radio frequency power, $1050 \mathrm{~W}$; nebuliser Ar flow rate, 0.791/min; auxiliary Ar flow rate, $1.21 / \mathrm{min}$; outer $\mathrm{Ar}$ flow rate, $15 \mathrm{l} / \mathrm{min}$. Data acquisition conditions were as follows: sweeps/reading 50; readings/replicate, 1; number of replicates, 3; dwell time, $100 \mathrm{~ms}$; scanning mode, peak-hopping.

\section{Data analysis}

Values are given as means and standard deviations, and data were tested by two-way ANOVA using the General Linear Models procedure of the Super ANOVA package (Abacus, Berkeley, CA, USA). Post-hoc comparisons were performed using Fisher's least significant difference procedures. Differences of $P<0.05$ were considered statistically significant.

\section{Results}

\section{Food intake and growth rate}

Inulin intake at the dose of $75 \mathrm{~g} / \mathrm{kg}$ showed only a tendency for the animals to decrease their food intake in this study (Table 2). The slight decrease in food intake in inulin-fed rats led to a significant decrease in weight gain $(P<0.05)$ at the end of the experiment in inulin-fed rats compared with controls. The lower energetic value of the inulin diets $(-4 \%)$ compared with the control diets may also be responsible for this reduced weight gain. In addition, food intake decreased significantly with increasing age, as expected (Table 2).

\section{Faecal recovery and intestinal absorption of dysprosium}

The gavaged amount of Dy of approximately $890 \mu \mathrm{g} / \mathrm{rat}$ was no different among the eight rat groups (Table 3). Faecal Dy levels averaged $81-137 \mu \mathrm{g} / \mathrm{g}$ faeces or $569-969 \mu \mathrm{g}$ in the whole collected $4 \mathrm{~d}$ faeces pool. Faecal Dy excretion decreased significantly under inulin intake and increased significantly with age. Consequently, the percentage of faecal 

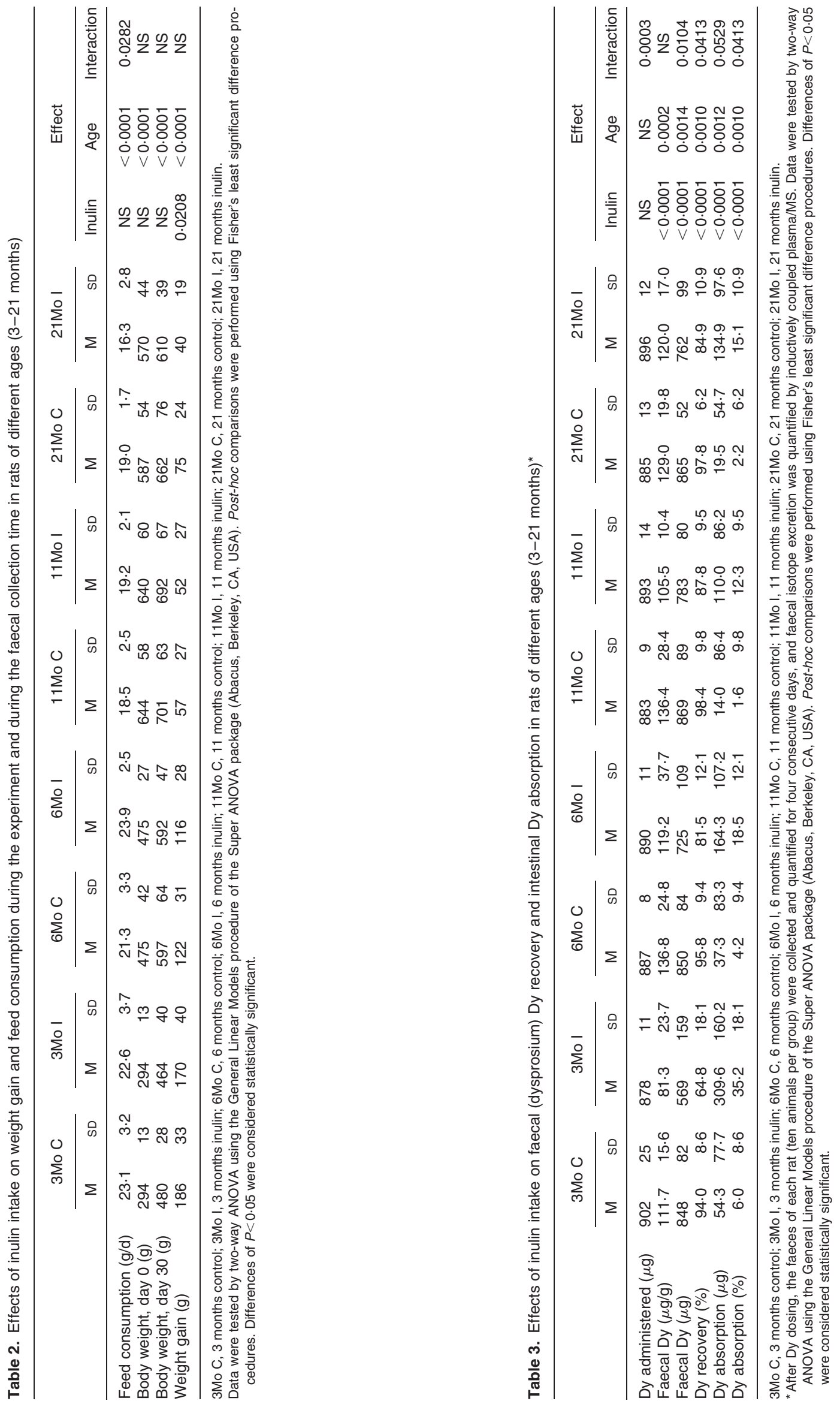
Dy recuperation was significantly lower under inulin intake than in the control rats, and significantly higher in the old rats than in the young adult or adult rats. In parallel, net $(\mu \mathrm{g})$ and relative $(\%)$ intestinal Dy absorption was significantly higher under inulin intake than in the control rats, and significantly lower in the aged rats than in the young adult or adult rats.

\section{Discussion}

The most commonly used faecal markers include colouring agents, polyethylene glycol, radio-opaque pellets and REE. Colouring agents such as carmine have been used as faecal markers to determine the time at which faecal collection can be started and stopped (Sian et al. 1996). Radio-opaque pellets, which can be recovered by physical extraction or identified using X-ray analysis, are used as faecal markers to ensure complete faecal collection in studies on man (Fairweather-Tait et al. 1997; Tahiri et al. 2001, 2003).

REE such as samarium, holmium, lanthanum, ytterbium and Dy are thought to be non-absorbable or absorbed in negligible amounts by the mammalian gut (Durbin et al. 1956) and have been traditionally used in animal experiments, particularly in determining the kinetics of digestion in ruminants (Crooker et al. 1982). They have also been used to determine nutrient absorption in some animal and human studies (Schuette et al. 1993; Fairweather-Tait et al. 1997; Coudray et al. 1998; Harvey et al. 2002; Matsui et al. 2002) in order to ensure complete faecal collection and reduce the faecal collection period. The first comprehensive use of REE as markers in mineral absorption studies was reported by Schuette et al. in 1993 in adult man. These authors observed a mean recovery of Dy of $104 \%$ and a Dy excretion profile closely paralleling that of ${ }^{70} \mathrm{Zn}$ and ${ }^{26} \mathrm{Mg}$. In contrast, Dy excretion did not correlate well with that of ${ }^{65} \mathrm{Cu}$.

In another study, Fairweather-Tait et al. (1997) evaluated the usefulness of REE as non-absorbable faecal markers for $\mathrm{Fe}$ isotopes in absorption studies in man. They employed three different REE (samarium, ytterbium, Dy) in three studies using three different $\mathrm{Fe}$ isotopes $\left({ }^{54} \mathrm{Fe},{ }^{57} \mathrm{Fe},{ }^{58} \mathrm{Fe}\right)$, reporting a mean recovery of samarium, ytterbium and Dy of $103 \%, 98 \%$ and $102 \%$, respectively. They also reported that Fe isotopes and REE had very similar faecal excretory patterns and showed that $\mathrm{Fe}$ absorption might be predicted from a $4 \mathrm{~d}$ faecal collection containing about an $80 \%$ excretion of REE. Ulusoy \& Whitley (2000) reported that excretion patterns of Fe isotopes and REE in human subjects were identical in only the first two or three faecal samples.

Finally in rat studies, Coudray et al. (1998) observed close faecal excretory patterns between faecal ${ }^{67} \mathrm{Zn}$ and ${ }^{65} \mathrm{Cu}$ and Dy. In addition, Matsui et al. (2002) reported that faecal Dy excretion closely paralleled that of ${ }^{67} \mathrm{Zn}$, and that most of the Dy and ${ }^{67} \mathrm{Zn}$ was excreted within $3 \mathrm{~d}$ of administration.

Based on previous works and findings, we addressed the questions of whether the intestinal absorption of lanthanides, in particular Dy, might vary with the age of the animals, and of whether it might be influenced by dietary composition, such as by adding inulin to the diet. Our results showed clearly that the percentage recovery of Dy in the faeces was less than $100 \%$ in the eight experimental groups. This percentage recovery was about $95 \%$ in the young and adult and about
$98 \%$ in the old and very old rats receiving the control diet, and was only $65 \%$ in the young, $81 \%$ in the adult and about $86 \%$ in the old and very old rats receiving inulin in their diet. The statistical analysis clearly showed that both inulin and age effects were significant in this study $(P<0 \cdot 0001$ and $P=0 \cdot 0010$, respectively). These results indicated that Dy might be partially absorbed in rats, and that this absorption might be modulated with dietary manipulation and varied with physiological states.

Ten Bruggencate et al. (2005) recently reported that dietary fructo-oligosaccharides increased intestinal permeability in rats. Inulin, used in our study, is a fructo-oligosaccharide that may increase intestinal permeability and thus increase Dy absorption. However, Sobotka et al. (1997) demonstrated that intestinal permeability, tested with ${ }^{51} \mathrm{Cr}$-EDTA, was not influenced by inulin administration, added as dietary fibre into patients' fibre-free enteral nutrition. Indeed, the mechanisms by which inulin increases mineral absorption are not clear yet. It is known that inulin is metabolised by the bacteria in the large intestine, leading to an increased production of SCFA, mainly acetate, propionate and butyrate (Levrat et al. 1991; Campbell et al. 1997). SCFA production lowers the luminal $\mathrm{pH}$, which increases mineral solubility and raises the mineral gradient between the luminal and serosal sides, thus allowing passive and active mineral transport to increase (Lopez et al. 1998; Scholz-Ahrens \& Schrezenmeir, 2002; Coudray et al. 2003). In addition, SCFA, especially butyrate, serve as a fuel for mucosal cells and stimulate cell proliferation, which could in turn increase the absorptive surface area of the large intestine (Sakata, 1987; Lupton \& Kurtz, 1993). These mechanisms may also be responsible for the increase in Dy absorption observed in this study.

Previous studies have already shown that some actinides and lanthanides can be absorbed by rats under particular conditions. Ulusoy \& Whitley (2000) investigated the excretion profiles of REE and stable isotopes of $\mathrm{Zn}$ and $\mathrm{Fe}$ in man and reported a mean recovery of $94 \%$ for the five REE, suggesting that some REE are absorbed much more than others. Recently, Matsui et al. (2002) reported that only about $90 \%$ of administered Dy was recovered in the rat faeces collected over 5 d. Sullivan et al. (1986) reported that the absorption and retention of uranium, plutonium, americium and curium was substantially increased by fasting and by adding mild oxidising agents, and decreased by adding reducing agents. Moreover, they reported that the absorption of promethium, a lanthanide, was also increased by adding mild oxidising agents. In another study, Sullivan et al. (1984) examined the effect of age on lanthanide absorption by rats; they reported that the absorption of promethium and plutonium from the gastrointestinal tract was substantially higher for neonatal than for adult rats. This is in agreement with our results, in which Dy absorption was higher in the growing and adult rats than in the old rats.

In conclusion, our results showed clearly that if intestinal Dy absorption is negligible in normal conditions, it may vary largely under nutritional conditions (inulin intake) or physiological states (age). Thus, the validity of using REE as faecal markers should be determined for individual nutritional and physiological states. Studies are also needed to confirm these results in man. 


\section{Acknowledgements}

The authors are grateful to ORAFTI (Tienen, Belgium) for providing the inulin product for this study. The authors thank Séverine Thien, Lydia Jaffrelo and Claudine Lab for their technical assistance.

\section{References}

Campbell JM, Fahey GC Jr \& Wolf BW (1997) Selected indigestible oligosaccharides affect large bowel mass, cecal and fecal shortchain fatty acids, $\mathrm{pH}$ and microflora in rats. $J$ Nutr 127, 130-136.

Coudray C, Bousset C, Tressol JC, Pepin D \& Rayssiguier Y (1998) Short-term ingestion of chlorogenic or caffeic acids decreases zinc but not copper absorption in rats, utilization of stable isotopes and inductively-coupled plasma mass spectrometry technique. $\mathrm{Br} \mathrm{J}$ Nutr 80, 575-584.

Coudray C, Demigne C \& Rayssiguier Y (2003) Effects of dietary fibers on magnesium absorption in animals and humans. J Nutr 133, 1-4.

Coudray C, Feillet-Coudray C, Gueux E, Mazur A \& Rayssignuier Y (2005a) Effect of inulin intake on intestinal absorption of zinc and copper in rats at different ages: a stable isotope study. J Nutr (In the Press).

Coudray C, Rambeau M, Feillet-Coudray C, Tressol JC, Demigne C, Gueux E, Mazur A \& Rayssignuier Y (2005b) The efficiency of intestinal calcium absorption is greater under inulin intake in aged rats than in young or adult rats: a stable isotope approach. Nutr $J$ (In the Press).

Crooker BA, Clark JH \& Shanks RD (1982) Rare earth elements as markers for rate of passage measurements of individual feedstuffs through the digestive tract of ruminants. J Nutr 112, 1353-1361.

Durbin PW, Williams MH, Gee M, Newman RH \& Hamilton JG (1956) Metabolism of the lanthanons in the rat. Proc Soc Exp Biol Med 91, 78-85.

Fairweather-Tait SJ \& Dainty J (2002) Use of stable isotopes to assess the bioavailability of trace elements: a review. Food Addit Contam 19, 939-947.

Fairweather-Tait SJ, Minihane AM, Eagles J, Owen L \& Crews HM (1997) Rare earth elements as nonabsorbable fecal markers in studies of iron absorption. Am J Clin Nutr 65, 970-976.

Harvey LJ, Majsak-Newman G, Dainty JR, Wharf SG, Reid MD, Beattie JH \& Fairweather-Tait SJ (2002) Holmium as a faecal marker for copper absorption studies in adults. Clin Sci (Lond) 102, 233-240.

Hutcheson DP, Venugopal B, Gray DH \& Luckey T (1979) Lanthanide markers in a single sample for nutrient studies in humans. J Nutr 109, 702-707.

Jandacek RJ, Heubi JE \& Tso P (2004) A novel, noninvasive method for the measurement of intestinal fat absorption. Gastroenterology 127, 139-144.

Kaur N \& Gupta AK (2002) Applications of inulin and oligofructose in health and nutrition. $J$ Biosci 27, 703-714.

Levrat MA, Remesy C \& Demigne C (1991) High propionic acid fermentations and mineral accumulation in the cecum of rats adapted to different levels of inulin. J Nutr 121, 1730-1737.

Lopez HW, Coudray C, Bellanger J, Younes H, Demigne C \& Remesy C (1998) Intestinal fermentation lessens the inhibitory effects of phytic acid on mineral utilization in rats. J Nutr 128, 1192-1198.

Lupton JR \& Kurtz PP (1993) Relationship of colonic luminal shortchain fatty acids and $\mathrm{pH}$ to in vivo cell proliferation in rats. $J$ Nutr 123, 1522-1530.

Matsui T, Okumura H \& Yano H (2002) Absorption of zinc from dietary casein phosphopeptide complex with zinc in rats given a soybean protein-based diet. J Nutr Sci Vitaminol (Tokyo) 48 , 247-250.

Mellon FA \& Fairweather-Tait SJ (1997) Stable isotope methods for studying nutrient mineral metabolism in humans. Endeavour 21, $12-18$.

Ohta A, Ohtsuki M, Baba S, Adachi T, Sakata T \& Sakaguchi E (1995) Calcium and magnesium absorption from the colon and rectum are increased in rats fed fructooligosaccharides. $J$ Nutr 125, 2417-2424.

Patterson KY \& Veillon C (2001) Stable isotopes of minerals as metabolic tracers in human nutrition research. Exp Biol Med (Maywood) 226, 271-282.

Sakata T (1987) Stimulatory effect of short-chain fatty acids on epithelial cell proliferation in the rat intestine: a possible explanation for trophic effects of fermentable fibre, gut microbes and luminal trophic factors. Br J Nutr 58, 95-103.

Saltzman JR \& Russell RM (1998) The aging gut. Nutritional issues. Gastroenterol Clin North Am 27, 309-324.

Scholz-Ahrens KE \& Schrezenmeir J (2002) Inulin, oligofructose and mineral metabolism - experimental data and mechanism. $\mathrm{Br} \mathrm{J}$ Nutr 87, Suppl 2, S179-S186.

Schuette SA, Janghorbani M, Cohen MB, Krug S, Schindler T, Wagner DA \& Morris SJ (2003) Dysprosium chloride as a nonabsorbable gastrointestinal marker for studies of stable isotope-labeled triglyceride excretion in man. J Am Coll Nutr 22, 379-387.

Schuette SA, Janghorbani M, Young VR \& Weaver CM (1993) Dysprosium as a nonabsorbable marker for studies of mineral absorption with stable isotope tracers in human subjects. $\mathrm{J} \mathrm{Am}$ Coll Nutr 12, 307-315.

Sian L, Mingyan X, Miller LV, Tong L, Krebs NF \& Hambidge KM (1996) Zinc absorption and intestinal losses of endogenous zinc in young Chinese women with marginal zinc intakes. Am J Clin Nutr 63, 348-353.

Sobotka L, Bratova M, Slemrova M, Manak J, Vizd'a J \& Zadak Z (1997) Inulin as the soluble fiber in liquid enteral nutrition. Nutrition 13, 21-25.

Sullivan MF, Miller BM \& Goebel JC (1984) Gastrointestinal absorption of metals $(51 \mathrm{Cr}, 65 \mathrm{Zn}, 95 \mathrm{mTc}, 109 \mathrm{Cd}, 113 \mathrm{Sn}, 147 \mathrm{Pm}$, and $238 \mathrm{Pu}$ ) by rats and swine. Environ Res 35, 439-453.

Sullivan MF, Ruemmler PS, Ryan JL \& Buschbom RL (1986) Influence of oxidizing or reducing agents on gastrointestinal absorption of U, Pu, Am, Cm and Pm by rats. Health Phys 50, 439-453.

Tahiri M, Tressol JC, Arnaud J, et al. (2001) Five-week intake of short-chain fructo-oligosaccharides increases intestinal absorption and status of magnesium in postmenopausal women. $J$ Bone Miner Res 16, 2152-2160.

Tahiri M, Tressol JC, Arnaud J, et al. (2003) Effect of short-chain fructooligosaccharides on intestinal calcium absorption and calcium status in postmenopausal women: a stable-isotope study. Am J Clin Nutr 77, 449-457.

Ten Bruggencate SJ, Bovee-Oudenhoven IM, Lettink-Wissink ML \& Van der Meer R (2005) Dietary fructooligosaccharides increase intestinal permeability in rats. $J$ Nutr 135, 837-842.

Ulusoy U \& Whitley JE (2000) Profiles of faecal output of rare earth elements and stable isotopic tracers of iron and zinc after oral administration. Br J Nutr 84, 605-617.

Van Loo J, Cummings J, Delzenne N, et al. (1999) Functional food properties of non-digestible oligosaccharides: a consensus report from the ENDO project (DGXII AIRII-CT94-1095). Br J Nutr 81, 121-132.

Zhao Z, Egashira Y \& Sanada H (2003) Digestion and absorption of ferulic acid sugar esters in rat gastrointestinal tract. J Agric Food Chem 51, 5534-5539. 